Fixed Point Theory, 21(2020), No. 2, 465-474

DOI: $10.24193 /$ fpt-ro.2020.2.33

http://www.math.ubbcluj.ro/ nodeacj/sfptcj.html

\title{
BEST PROXIMITY POINTS THEOREM IN $b$-METRIC SPACES ENDOWED WITH A GRAPH
}

\author{
KAMAL FALLAHI* AND GHASEM SOLEIMANI RAD** \\ * Department of Mathematics, Payame Noor University \\ P.O. Box 19395-4697, Tehran, Iran \\ E-mail: fallahi1361@gmail.com (Corresponding author) \\ ** Department of Mathematics, Payame Noor University \\ P.O. Box 19395-4697, Tehran, Iran \\ E-mail: gh.soleimani2008@gmail.com
}

\begin{abstract}
In this paper the existence and uniqueness of best proximity point for Reich-type contraction on $b$-metric spaces endowed with a graph is established. These results are significant, since we replace the condition of continuity of mapping with the condition of $G$-continuity of mapping and we consider $b$-metric spaces endowed with a graph instead of metric spaces, under which can be unified some theorems of the existing literature.
\end{abstract}

Key Words and Phrases: $b$-metric space, best proximity point, $P$-property, $G$-proximal.

2010 Mathematics Subject Classification: 41A52, 41A65, 05C40, 47H10.

Acknowledgments. The authors are thankful to the editor and the referees for their valuable comments to improve the paper.

\section{REFERENCES}

[1] M. Abbas, V. Rakoćević, A. Iqbal, Fixed points of Perov type contractive mappings on the set endowed with a graphic structure, RACSAM, 112(2018), no. 1, 209-228.

[2] A. Aghanians, K. Fallahi, K. Nourouzi, Fixed points for G-contractions on uniform spaces endowed with a graph, Fixed Point Theory Appl., 2012(2012), Art. ID 182, 12 pages.

[3] S.M.A. Aleomraninejad, Sh. Rezapour, N. Shahzad, Some fixed point results on a metric space with a graph, Topol. Appl., 159(2012), no. 3, 659-663.

[4] A. Amini-Harandi, Common best proximity point theorems in metric spaces, Optim. Lett., 8(2014), no. 2, 581-589.

[5] C.B. Ampadu, Best proximity point theorems for non-self proximal Reich type contractions in complete metric spaces, Fixed Point Theory, 19(2018), no. 2, 449-452.

[6] I.A. Bakhtin, The contraction mapping principle in quasimetric spaces, Func. Anal., Gos. Ped. Inst. Unianowsk., 30(1989), 26-37.

[7] J.A. Bondy, U.S.R. Murty, Graph Theory, Springer, 2008.

[8] S. Czerwik, Contraction mappings in b-metric spaces, Acta Math. Inform. Univ. Ostrav., 1(1993), no. 1, 5-11.

[9] K. Fallahi, A. Petruşel, G. Soleimani Rad, Fixed point results for pointwise Chatterjea type mappings with respect to a c-distance in cone metric spaces endowed with a graph, U.P.B. Sci. Bull. (Series A)., 80(2018), no. 1, 47-54. 
[10] J. Jachymski, The contraction principle for mappings on a metric space with a graph, Proc. Amer. Math. Soc., 136(2008), no. 4, 1359-1373.

[11] M.A. Khamsi, N. Hussain, KKM mappings in metric type spaces, Nonlinear Anal., 73(2010), 3123-3129.

[12] S. Reich, Some remarks concerning contraction mappings, Canad. Math. Bull., 14(1971), 121124.

[13] S. Sadiq Basha, Extensions of Banach's contraction principle, Numer. Funct. Anal. Optim., 31(2010), 569-576.

[14] S. Sadiq Basha, Discrete optimization in partially ordered sets, J. Global Optim., 54(2012), 511-517.

[15] S. Sadiq Basha, N. Shahzad, C. Vetro, Best proximity point theorems for proximal cyclic contractions, J. Fixed Point Theory Appl., 19(2017), no. 4, 2647-2661.

[16] V. Sankar Raj, A best proximity point theorem for weakly contractive non-self-mappings, Nonlinear Anal., 74(2011), 4804-4808.

[17] V. Sankar Raj, Best proximity point theorems for non-self mappings, Fixed Point Theory, 14(2013), 447-454.

[18] A. Sultana, V. Vetrivel, Best proximity points of contractive mappings on a metric space with a graph and applications, Applied Gen. Topol., 18(2017), no. 1, 13-21.

[19] C. Vetro, Best proximity points: convergence and existence theorems for $\rho$-cyclic-mappings, Nonlinear Anal., 73(2010), 2283-2291.

Received: June 21, 2018; Accepted: October 18, 2018. 